\title{
Prophetic Populism and the Violent Rejection of Joe Biden's Election: Mapping the Theology of the Capitol Insurrection
}

\author{
Matthew Rowley ${ }^{1}$
}

\begin{abstract}
For President Donald Trump's most committed Christian devotees — those with ears to hear-his rise to power was prophesied, and the 2016 victory was miraculous. Prophets again foretold re-election in 2020. These charismatic Trump supporters tended to come from outside the main denominations, and when the electoral college swung towards Joe Biden, the results were not accepted. In rejecting the election, they became fellow travellers with more overtly militant and conspiratorial groups-sometimes sharing a stage with them. This article describes the discourse of prophetic populism from 2011 to 2021 -focusing in particular on the three months from the 2020 election to the storming of Capitol Hill to the inauguration of Joe Biden. Although Trump repeatedly says, Promises Made, Promises Kept', these prophetic promises did not materialise_leading some to try to force God's hand. This article explores the reaction to three consecutive disappointments that took their toll on prophetic populism: the declaration of Joe Biden as president-elect in November 2020, the certification of his victory in early January 2021 and the inauguration later that month. It demonstrates the power of a relatively new force in conservative politics, the flexibility of beliefs in divine involvement and the resilience of these beliefs in light of weighty disconfirming evidence. ${ }^{2}$
\end{abstract}

Prophetic Populism and the Violent Rejection of Joe Biden's Election:

Mapping the Theology of the Capitol Insurrection'

Keywords: Trump; Biden; Prophecy; 2020 Election; 2021 Capitol Insurrection

\section{Introduction}

For some of President Donald Trump's most committed Christian devotees - those with ears to hear-his rise to power was prophesied, and the 2016 victory was miraculous. Prophets again foretold re-election in 2020. These charismatic Trump supporters tended to come from outside the main denominations, and when the electoral college swung towards Joe Biden, the results were not accepted. In rejecting the election, they became fellow travellers with more overtly militant and conspiratorial groups - sometimes sharing a stage with them.

This article explores the contours of prophetic populism from 2011 to 2021 -focusing in particular on the three months from the 2020 election to the storming of Capitol Hill to the aftermath of the inauguration of Joe Biden. 'Prophetic populism' can be understood in two senses. First, these Trump supporters aligned themselves with populists and exhibited traits common to populists like the

\footnotetext{
${ }^{1}$ Dr Matthew Rowley, FRHistS, Honorary Visiting Fellow, Department of History, Politics and International Relations University of Leicester, Leicester, LE1 7RH, UK. E-mail: mpr22@le.ac.uk. https://orcid.org/0000-0003-2762-0667

${ }^{2}$ I would like to thank Richard Lee Rogers, Michael McKoy and anonymous reviewers for their constructive criticism of earlier drafts.
} 
denigration of 'elite' forms of knowledge as they differentiate between 'real' and less-than-real Americans (Van der Tol and Rowley, 2021). In this sense, many of these populists also believed God had spoken prophetically about Trump's victory. Second, they are 'prophetic' populists in that they believe God provided secret information to a select few through the medium of prophecy. Just as populists separate 'the people' (a part of the population) from the people (the totality of the population), prophetic populists differentiate the 'real results' of the election (as revealed by God) from the real results of the election (as certified through democratic and constitutional means). In this instance, divine revelation relativises democratic results. In this sense, prophecy undergirds the claims of populists. Sometimes they even refer to themselves as 'populists', as will be shown later. At the Jericho March/Stop the Steal rally in Washington D.C., one prophet preached on the 'beginning of a Christian populist uprising' (12 Dec 2020), and on the Firewall broadcast, another prophet denounced the stolen election and prophecied revival that would increase the number of 'activists of the Christian populist movement' (26 Aug 2021).

Anyone with close connections to a sitting president is worthy of close public scrutiny. However, before the assault on the Capitol, many of these prophets largely flew under the radar. When they were not overlooked, the 'prophetic' aspects of their relationship with Trump were easily dismissed. In Unholy (2020), Sarah Posner offered the first detailed look at these prophets and their direct access to the president. Their fielty to the president has increased since Posner published her work. Since November 2020, these prophets have vigorously claimed the strongest of all proofs that the election was stolen-divine revelation. Because the opposition to Biden's election turned violent, this article will also be of interest to scholars who study the political and martial use of supernatural claims (Rowley and Hodgson 2022). On 6 January lethal violence followed in the wake of prophetic and miraculous discourse employed in the service of seizing political authority for Trump. Now major news outlets covered these prophecies in earnest. The influence of prophecy on politics, it now seemed, was self-evident.

The slowness of scholars to notice prophetic populism stands in stark contrast to the frequency with which prophets promised Trump's victory. From 2011 to the present, they recorded their predictions in dozens of books that line the shelves of major booksellers, they turned their prophecies into a feature film and disseminated these prophecies in sermons, on the radio and television and on podcasts and blogs. They personally told Trump that God promised his election and then broadcast these statements to the world. This article utilises all of these sources to understand prophetic populists and their effect on modern politics. It proceeds chronologically. First, I explore the longer history of what Brad Christerson and Richard Flory call 'Independent Network Charismatic' Christianity (sometimes called the 'New Apostolic Reformation') and what Damon Berry calls 'prophecy voters'. Then, following Richard Lee Rogers, I argue that it was support for Trump that led the prophets to walk together with other conspiratorial and militaristic groups. I then overview prophetic utterances about Trump's electoral success from 2011 to November 2020. The bulk of the article then explores how these Christians responded to obstacles in the way of prophetic fulfilment. It focuses on three critical moments: the declaration of Biden's victory in November 2020, the failed attempt to halt the certification of Biden's victory in early January 2021 and the inauguration of a new president later that month. The article closes by briefly surveying various responses to failed expectations and how some charismatic leaders are trying to save the credibility of political prophecy. It demonstrates the power of a relatively new force in conservative politics, the flexibility of their beliefs in divine involvement and the resilience of these beliefs in light of disconfirming evidence. 


\section{INC Christianity}

Brad Christerson and Richard Flory's The Rise of Network Christianity was the first systematic overview of the 'fastest-growing subset of Christianity in the United States and around the world' (2017: 147). They coined the term Independent Network Charismatic (INC) Christianity to describe this group. It is also known by the name given by an INC leader and scholar, C. Peter Wagner, who called them the 'New Apostolic Reformation' (NAR). In contrast to previous waves of Charismatic Christianity, Christerson and Flory described unique features of INC:

"1) They do not seek to build a "movement" or to create affiliated franchise congregations using a particular name. 2) They are not primarily focused on building congregations in the traditional sense, but rather seek to influence the beliefs and practices of believers regardless of congregation or affiliation, including those who are not affiliated with any congregation or religious group. 3) They seek to transform society as a whole rather than saving individual souls and building the church. 4) Instead of being formally organized into a "movement" or "denomination" the various leaders and ministries in this category are highly connected by networks of cooperation' (2017: 8).

They are a 'collection of strong leaders' who 'gain their legitimacy and influence from their perceived ability to directly access supernatural power to produce "signs and wonders" rather than through speaking ability, educational credentials, or position in a hierarchy" (2017: 11).

As another contrast with previous Charismatic movements, the eschatological orientation of INC leaders tends to be postmillennial, meaning that Christians work to improve conditions on earth as they build the kingdom of God in the here and now (2017: 12). In this view of the eschaton, 'God has empowered believers through the Holy Spirit to literally create heaven on earth through their gaining power in the various sectors of society' (2017: 92). Much of this kingdom-building takes the form of 'spiritual' demolition as they make concerted spiritual attacks on "'territorial" demonic forces' (2017: 28-29). Yet, many INC leaders seek to exercise dominion over cities, governments and whole regions. They seek to wrest dominion from Satan-a dominance he stole from Adam. Through Christ they lay claim to the "Seven Mountains of Culture": religion, education, family, media, arts and entertainment, and business' (2017: 31). The battle has been going on for thousands of year. INC 'leaders have developed a protocol for defeating demonic "territorial spirits" that control certain geographic areas and thus keep Satan in charge of the seven mountains of culture in those areas: research [into demonic strongholds in a given region], prophecy [declaring God's strategy], and intercession [through prayer and fasting]' (2017: 93).

Given this focus on improving earthly conditions, one might assume this movement had a well-oiled political arm. However, Christerson and Flory are keen to emphasise the opposite. Yes, they hold large prayer rallies, and sometimes politicians participate. Yes, they seek to promote kingdom-minded politicians (2017: 98-99). However, they have nothing comparable to other conservative evangelicals (like the Concerned Women of America, Ethics and Religious Liberty Commission, Family Research Council, Faith and Freedom Coalition, National Organization for Marriage, Traditional Values Coalition) (2017: 100-01, 135-36). Christerson and Flory end their account of INC Christianity in 2016 when Trump was still a candidate. At the time, they assessed, 'generally INC Christians are not known (or at least not known yet) for having the ability to deliver votes or raise money to a degree that would allow them to influence policy at the national level' (2017: 136-37). However, over the last four years, INC leaders directly influenced President Trump, mostly through prayer meetings and rallies in which Trump was sometimes present. However, their influence remained largely in the background, even when their prophecies about Trump's 2016 and 2020 victories made headlines. 
In 'Voting in the Kingdom', Damon Berry picks up the narrative of INC Christianity in his analysis of Trump support, ending his account in January 2020.

'They supported Trump, not because of the president's character, or even his policies, but so they would be obedient to what they perceived as God's plan.... These particular Christian Trump supporters, then, are not values voters who choose candidates on the grounds of personal character. Neither are they necessarily nostalgia voters looking for a return to an imagined golden age. Rather, they are prophey voters looking forward to the creation of the Kingdom of God on Earth by citizens acting on divine instructions delivered through the leaders of the New Apostolic Reformation' (2020: 72).

When there were other, more 'godly', Republican candidates, prophecy voters chose Trump because God chose Trump. The logic was simple. Most did not initially like Trump, so supporting him was an act of faith. The transition from disdain to devotion was dramatised for cinema audiences in The Trump Prophecy, and it also appears in many of their books. His full-throttled attacks on candidate Hillary Clinton strengthened their conviction that Trump was the best protector of their values and policies, and they vigorously defended their defender.

Charismatic prophets have long been proponents of 'conspiratorial narratives'. For example, many perceive a ubiquitous and insidious Marxist agenda behind cultural clashes, they believe the levers of power are controlled by unelected and unaccountable forces known as the Deep State and they often frame unfavourable reporting as 'Fake News' (2020: 71). As they tilled the conspiratorial ground, QAnon found fertile soil in which alternative facts might take root. The central myth of QAnon is that Trump is fighting a cabal of Democratic leaders who want to destroy the country-their depravity even stretching to the worship of Satan and the sexual trafficking of children. This link between prophecy and conspiratorial thinking is evident in two works by James Beverley. In God's Man in the White House (2020a) Beverley catalogued over 500 prophecies made about Trump (2020a). His next book, The QAnon Deception (2020b), looked directly at conspiratorial thinking. He argued that many Charismatic prophets and QAnon followers share a common trait: both hold dogmatically to the belief in Trump's victory in a way that is impervious to disconfirming evidence. The events leading up to the January 6th insurrection drove this point home. In 'Spiritual Warfare and the Apocalypse', Richard Lee Rogers explored the relationship between prophetic supporters of Trump and other conspiratorial or militaristic groups whose version of Christianity was primarily cultural or symbolic. '[1] t was the appeal of Trumpism', he writes, 'that ultimately led to the formation of an ideological alliance between the Christian and non-Christians wings of the far right'. He notes how 'QAnon incorporated evangelical apocalyptic themes, including converting hopes for an end-times great awakening into a desire for a utopian age free from the perversions of the Deep State' (2021: 92-93). He also briefly mentioned the alignment of the New Apostolic Reformation with Marianist Catholicism, a pairing that I explore in more detail elsewhere. Rogers' narrative ends shortly after the 6 January insurrection.

During the Trump presidency, these Charismatics supported his agenda with a high degree of consistency. Their vocal support was often considered as part of the wider evangelical movement. Although this is a correct classification in many ways, the fact that they were 'prophecy voters' made their support for Trump distinct. It was the prophetic element, as will be detailed later, that undergirded their adamantine opposition to Biden's victory. INC Christianity dramatically burst onto the scene during the 6 January 2021 insurrection. Shortly after that, Christerson wrote an article for The Conversation on how these prophets provided religious motivation for the insurrection. 
Christerson's article briefly overviewed some of the prophecies and miracles associated with Trump's re-election. In this article, I delve into these prophecies in greater depth. As Beverley shows in his catalogue of over 500 Trump prophecies, many Charismatics believe God started revealing the significance of Trump in prophecies dating to 2005 (Bill Yount), 2006 (Kim Clement), 2007 (Kim Clement) — and the prophecies start increasing in number and specificity in 2011 (2020a). Many even believe the prophecies began in Loreto (Italy) in the 1980s (e.g. Strang, 2018a, 2020a). Over the last decade, prophecies have played an increasingly important part in sanctifying Trump as God's anointed. The bulk of the article then focuses on how the prophets responded to what looks, to an outsider, like the repeated failure of clear and confident prophecies.

\section{Preparing the Way for Trump (2011-Nov 2020)}

Prophecy and politics blend in three common ways, and an individual or group might practice all three. First, many take a 'prophetic stand' against the injustices perpetrated against the weak. Like Hebrew Bible prophets, they confront injustice in God's name. Leaders in America's Black church, like Rev Dr Martin Luther King Jr., have a long history of donning this prophetic garb. His niece, Alveda C. King, also presents herself in a similar role as she opposes racism and abortion. She also supports Donald Trump, as will be discussed later.

The second type of prophecy involves mapping scriptural prophecy onto modern events. John Hagee is a prominent example. This mega-church televangelist found eschatological significance in the socalled 'Blood Moons' of the late 2010s. He used biblical prophecy to warn against nefarious global forces running the New World Order and the Deep State. Since early 2020, he has decried the demonic influences behind the Left's response to COVID-19, again finding the pandemic prophecied in Scripture. On 14 May 2018, he walked onto the stage of his own prophetic drama when he delivered the benediction at the opening of the American Embassy in Jerusalem. When he subsequently wrote Earth's Last Empire, one section of the book was titled 'Donald J. TrumpMaking America Great Again' (2018: 211). Similarly, Gene Ho, Trump's personal campaign photographer, ended his book with a discussion of 'Apocalypse: $\dot{\alpha} \pi 0 x \dot{\alpha} \lambda u \psi \iota \varsigma$ ' and the signs that God is fulfilling prophecy through Trump (2018: 161).

The third type of prophecy is pronounced among INC leaders, although not exclusively. They receive new prophecies, new visions and new words from the Lord. As will be shown below, INC leaders believe that God not only spoke through Scripture, he also speaks to and through living humans. For example, shortly after the 6 January insurrection, one leader claimed the Lord was speaking through him about 'a righteous rebellion [that] is upon the land'. This was God, through his mouthpiece, declaring the assault on the capital 'righteous'. The prophet did not appeal to Scripture to reach this conclusion or draw on Christian legal theory. Rather, these direct words from God were authoritative and carried the divine imprimatur. This post-insurrection utterance stands in a long line of prophecies about Trump stretching back a decade. To begin understanding the impact of INC Christianity on post-2020 election politics, we must first explore this much longer history. James A. Beverley recently catalogued over five hundred prophecies related to Trump, a few of which are explored below (2020a). The frequency and specificity of these predictions are a departure from the norm.

These prophets might easily be overlooked or dismissed. That would be a mistake, as Sarah Posner recently argued in Unboly. Her account is one of the few books that engage with this 'formidable spiritual army of self-styled prophets' (2020: 52). It would be easy for 'elites' who occupy think tanks and universities to dismiss them as insignificant. They certainly come from the margins, but they are anything but marginal. Prophets have hosted Trump in their churches, met with him individually and 
in groups, served as his spiritual advisor, served as his personal photographer, consistently opened for him at rallies, spoken at political conventions and prayed at his inauguration - all the while tirelessly defending God's anointed in print, on television and over the radio and in sermons. Treating them as 'marginal' or 'insignificant' speaks volumes about the values of the person giving them this designation. The very fact that these prophets come from outside the denominational and educational mainstream accords with Trump's own anti-elitism and populism (Posner 2020: 247). Their marginal status is understood as an asset, not a liability. They categorically reject 'elite' definitions of what it means to be significant. They do not publish with mainstream evangelical publishers (Baker, Eerdmans, IVP, Fortress) but instead use smaller presses (Defender, Elijah List, FrontLine, Killer Sheep). Some of these leaders are involved in POTUS Shield, a network of prayer warriors who fight for Trump in the courts of heaven. This ethnically diverse group also includes military leaders like General Jerry Boykin. INC Christians tend to be more multi-racial (Graham, 2021), complicating accounts of Trump's appeal that rely heavily on racism as the explanatory factor. As Posner comments, many religious rallies supporting Trump are very diverse, 'crushing the impression created by Trump's nearly all-white MAGA rallies' (2020: 63; cf. Rowley 2021: 15-19, 38-41). If Trump's religious rallies (e.g. C-SPAN, 2020) were isolated and taken as the barometer of his attitudes towards minorities and women, it would be easy to conclude that he was one of the most diversity-affirming presidents in history. After years of negative reporting on Trump and racism, the election results were surprising: whites increasingly voted Democratic, but minority support for Trump grew markedly from 2016 to 2020.

In uttering new prophetic words about Trump, the prophets often slot their revelations into a prophetic lineage. Their narratives build on a cornerstone that others might reject, the 2011 prophecies of a retired firefighter. Mark Taylor initially thought God foretold a Trump presidency in 2012, but his timeline was off by a few years (2019: 4-5). Taylor's The Trump Prophecies blends the second and third type of prophecy into a hopeful vision of a restored America with Hillary Clinton behind bars. Other prophets, though seeing Trump as God's prophetically chosen leader, were not as hopeful for America (e.g. McGuire and Anderson, 2018). Taylor thought God, through Trump, would bring down the Lucifer-backed New World Order. With the help of Liberty University, Taylor's prophecies hit the big screen (released in 1,200 theatres) before the 2018 mid-term elections. The Trump Prophecy charts Taylor's slow and uneasy acceptance of God's revelations about Trump. However, it opens with a clear declaration: "The Spirit of God told me "I have chosen this man for such a time as this"'. Through the film, the nation was being asked to follow Taylor's journey from doubt to certainty, from ignorance to the acceptance of God's will. The film's reception was mixed, and many evangelicals vocally opposed it (Markoe, 2020).

Lance Wallnau is a second giant among the prophets. In Sarah Posner's words, he is 'an evangelist whose popularity and visibility have skyrocketed in the Trump era' (Posner, 2020: 31). Wallnau's central argument in God's Chaos Candidate (October 2016) is that God chose Trump as a modern-day Cyrus to come in like a 'wrecking ball to the spirit of political correctness!' He published these prophetic words long before the election victory (Wallnau, 2016: 21). His book told of several meetings with the president to be (direct access to the president is shockingly common among INC leaders). A month before the 2020 election, Wallnau published the sequel God's Chaos Code, in which he makes the following prediction: 'This means it could be a Trump landslide on election day, and then-surprise, surprise-ballots begin to arrive, postmarked November 3, 2020, with time stamps of 9:00 p.m., 10:00 p.m., or even 11:59 p.m. We could see within days that landslides turn into a margin, and then potentially a Trump defeat'. The uncertainty unleashed by a stolen election would ultimately lead to Antifa and Black Lives Matter 'street units' making an 'open assault on America'. 
The Supreme Court might 'end up appointing Trump as president during a period of unparalleled national chaos' (71). Speaking on The Eric Metaxas Show on 20 November 2020, he thought the beginning parts of this prophecy were being fulfilled. Wallnau and Metaxas spoke of a fight to the death that might be necessary to thwart the stolen election.

Many people popularise the prophecies of others. For example, Alveda C. King finished America Return to God shortly after God, through 'We the People', raised Trump to power. Her book repeated the influential prophecies of the Messianic Rabbi Jonathan Chan. She concluded on the following note: 'While there are prophecies comparing President-Elect Trump to King Cyrus in the Bible during the days of Daniel, Nehemiah and Ezra, as time passes much more will be revealed' (2016: 152; cf. Cahn, 2017). The foremost populariser is Stephen E. Strang, a journalist and founding editor of Charisma Magazine. He has frequently defended the president in print, most notably in God and Trump (2018a, with a foreword by Mike Huckabee), Trump Aftershock (2018b, with a foreword by Jerry Falwell Jr.), God, Trump and the 2020 Election (2020a, with a foreword by Eric Metaxas), God, Trump, and COV ID-19 (2020b, with a foreword by Lori Bakker). Right before the election, the October 2020 issue of Charisma was dedicated to 'Why Most Charismatics Support Trump'. Strang does not claim to be a prophet. He promotes the prophetic interpretations of Taylor, Cahn, Wallnau, Hagee and others as Trump fights against the ungodly Deep State.

\section{Prophetic Entrenchment (Nov 2020-Jan 2021)}

Present-day claims to election fraud do not take place in a vacuum. To differing degrees and for various reasons, there is a growing bipartisan distrust of the democratic process. Some on both sides of the political aisle are willing to dispute the democratic process when it suits their agenda. In other words, prophetic certainty takes place in the context of electoral doubt. On one point, there is widespread bipartisan agreement: 2020 was an irregular election season. Trump's soaring economy took a hard hit because of COVID-19 and the concurrent protests over racism raised the stakes of the election. Crucially, many prophets believe the virus and the protests were engineered or exploited for political ends. Given these assumptions, calls for expanded mail-in voting access were interpreted as further attempts to thwart the will of the people (remember Wallnau's pre-election prophecy cited above). When the electoral college slowly swung towards Joe Biden, the results were not accepted by many Republicans. Some claimed prophetic proof of Trump's victory. The frequency and specificity of prophecies about the election made it difficult to entertain alternative facts. In the days after the election, Trump's spiritual advisor held a series of prayer meetings. Paula White denounced 'sorcery', 'witchcraft' and 'demonic covenants' working against the divinely promised re-election. She 'declared' and 'claimed' election victory for God's anointed. She invoked miraculous battles from Scripture as she spoke in tongues and claimed present-day miracles, dreams, visions and prophecies. She declared that 'angels have been dispatched from Africa' to fight election fraud. The prophetic resistance to Biden's victory was picking up steam (Grantham-Philips, 2020).

Stephen Strang's podcast, The Strang Report, provides a window into the evolving resistance. The prophet Dutch Sheets said the results are 'going to be overturned and President Trump is going to be put back in office for four years' (5 Nov). A week later, Rabbi Curt Landry declared that all the prophets sang from 'the same sheet of music, that Donald Trump was going to do two terms.... And basically, the prophets were right'. He appealed to 'fraud' in order to explain the gap between the prophesied results and the results claimed by the mainstream media $(13 \mathrm{Nov})$. At the end of the month, the prophet Mario Murillo, declared God said he was 'rolling up my [God's] sleeves and doing some things that even are going to scare you' (30 Nov). Dutch Sheets was back on the show unveiling 
'Operation Valkyrie', a dream-revealed strategy to topple election fraud (4 Dec). These dreams kicked off a nationwide prayer push that some believed angels visibly participated in. Three days later, Johnny Enlow declared that Trump had won, and God would overturn the results. He then uttered new words from the Lord (7 Dec). Then Mike Lindell (of 'My Pillow' fame) detailed proofs of election fraud (22 Dec). His face was on the cover of Charisma in January 2021. Another podcast that day was devoted to Steve Bannon's recent talk about God's agency and election fraud at a prayer meeting. Bannon said 'the Holy Spirit works through human instruments, right, and we're those instruments, so it's time to get to work'. Then Mario Murillo was on the podcast again, this time arguing that the alignments of Jupiter and Saturn in late December were a 'wink from heaven' bringing election comfort $(23$ Dec).

One of Trump's most vocal supporters, the best-selling author Eric Metaxas, regularly features miracles on The Eric Metaxas Show. On 20 November, Lance Wallnau was his guest, repeatedly declaring Trump's election victory. The prophetic promises clashed so clearly with the unfolding events. Cognitive and spiritual pain was evident in Metaxas' words: 'I have never, literally never in my life, been on a faith roller coaster, I have always had strong faith, but the facts of this case are so difficult'. More prophecy would be the solution to what seemed like failed prophecy. On the 8 December show, Metaxas interviewed the founders of a new organisation, Jericho March, who heard a 'spoken voice' from God and experienced an 'open vision' to peacefully re-enact Joshua's miraculous conquest. They would 'blow the shofars' and 'expect the heavenly hosts [armies] to listen, and we're fighting with the courts in heaven'. Shofars were ceremonial trumpets used by the biblical Israelites in worship and military campaigns. Jericho March would circle seven times around political buildings and pray election fraud would fall. Metaxas called this revelation 'miraculous and amazing'. In the film, The Trump Prophecy, the shofar brought about changes 'in the spirit realm. It becomes a supernatural weapon. It's a declaration by God's people that we are putting Him on the throne over our nation'.

Jericho March and Stop the Steal organised a large rally in Washington D.C. on 12 December 2020. ${ }^{3}$ Part worship service; part political rally, the speakers sought to turn water into wine but mostly mixed oil and water. They conflated Trump with Jesus; dying for America with dying for sins; spiritual warfare with physical warfare; and political conquest with worship. Trump's consecrated followers fought against cowardly, evil republicans. Christian Zionism formed a key thread, as did themes of exorcism and witchcraft. Speakers ranged from a Catholic archbishop to Lieutenant General Mike Flynn. Metaxas opened the rally saying 'we are here because we know He is the God who does real miracles', declaring that 'when God gives you a vision, you don't need to know anything else'. Divine revelation was the epistemic trump card. A Catholic group brought Our Lady of Guadalupe on stage and linked Trump's struggle with that apparition. Alex Jones, of InfoW ars fame, declared 'God is on our side' and vowed 'Joe Biden will be removed'. He pronounced 'the beginning of the Great Revival before the Antichrist comes!' and thundered that 'Revelation is fulfilled!' George Washington knew 'God controlled battlefields'. Leon Benjamin, an African American bishop, preached on Joshua 6 before blowing the shofar. No walls came tumbling down. During the rally, Metaxas introduced several prophets. One darted between the miracle at the Red Sea, the Ottoman conquest of Israel, the Pilgrim landing in 1620 and Trump's war against election fraud. Another focused on 'spiritual warfare' and predicted the 'beginning of a Christian populist uprising'. A third tied the present struggle to the Hanukkah miracles. From on high, Trump's helicopter flew, and he later tweeted

\footnotetext{
3 The six-hour YouTube video on which I based the following three paragraphs was removed, but Rod Dreher also offers a thorough summary (2020).
} 
approval. Miracles and prophecy took centre stage in a bid to secure political authority. Violence was not far behind, as some militant Trump supporters clashed with counter-protestors. Through sharing the same stage, faith leaders became fellow travellers with far-right militia groups and provocateurs like Alex Jones. Proclamations of the divine voice pulled a sacred canopy over armed opposition to Joe Biden.

\section{God Helps those who Help God's Hand (6 Jan 2021)}

In the month after the Stop the Steal rally, prophets continued to declare Trump's victory. For example, on 4 January, Pat Robertson told his 700 Club audience of 'Something very dramatic that will change the outcome of that vote.... The holy spirit of God will enter into this situation'. God was about to act. Two days later, as Congress certified Biden's victory, a 'Save America' rally was held in front of the White House. Paula White asked for divine protection and said 'we believe in miracles' (The Hill, 2021). Trump then praised his courageous followers, decried weakness and separated real Americans from election-stealing imposters. The crowd chanted 'Fight for Trump!' Before directing them to march on the Capitol, Trump said 'we fight. We fight like Hell, and if you don't fight like Hell, you're not going to have a country anymore' (Rev., 2021).

During an online prayer meeting, prominent religious and political leaders asked for a miracle, mentioning Israel before the Red Sea (Smietana, 2021). One evangelical protestor crossed the country after God gave a 'burning bush' sign (Dias and Graham, 2021). Jericho March circled buildings and blew shofars in a re-enactment of the battle of Jericho (Smietana, 2021). However, after the assault, they edited their website and issued a statement that distanced themselves from violence (Jericho March, 2021). Members of the Proud Boys - a paramilitary group frequently accused of racism and known for violent confrontations - stopped to pray for divine protection and blessing before moving on to the Capitol (Dias and Graham, 2021). Elsewhere, authorities later discovered unexploded pipe bombs. Some who breached the Congress building were equipped to take hostages. The congressional birds had flown.

In the wake of the 6 January attack on Capitol Hill, ProPublica created a database of over five hundred cellphone videos. These videos were uploaded to Parler, a right-wing social media site, between 12:00 and 6:00 PM. The database of Parler videos reveals many things about how religious rhetoric and the incitement to violence can go hand in hand. First, there was an all-pervading sense that the protestors were tricked and trapped by the Left, requiring aggressive defence. In their eyes, their protest was rational, restrained and done in an effort to uphold the law. Second, pro-Trump protestors viewed their actions in light of what they saw as a summer of Leftist violence. They continually asserted that they were more peaceful and restrained than Black Lives Matter, Antifa or Anarchists. Third, many claimed the assault on the police were perpetrated by Antifa (e.g. 3:27, 5:06). Fourth, the videos show considerable racial diversity, and several persons filming comment approvingly on Trump's appeal to minority voters. Fifth, the videos reveal people caught up in a historic moment-repeatedly comparing their actions to the events of America's founding. Sixth, many came prepared with gas masks, crowbars and combat gear. The casual nature of violent threats is chilling. Once breaching the Capitol, many call out for Nancy Pelosi and Mike Pence in a sinister and taunting way. One man said 'My first three thousand rounds will waste in Washington. ... Look at the Crusade flag' over there (2:26). Another talked at length about why Mike Pence should be executed (3:20). Finally, many persons say that Trump called for, or at least approved of, their actions at the Capitol.

How was Christ represented in the assault? Although it is hard to tell the religious beliefs or denominational affiliation of those seen in the videos, a survey shows the pervasive nature of 
Christian theology and symbolism. Jewish and Christian symbols were ubiquitous (Parler 1:41; 2:06; $2: 17 ; 2: 33 ; 2: 28 ; 2: 54 ; 3: 35 ; 3: 48)$. These symbols must be taken seriously, writes Robert P. Jones, an authority on white Christian nationalism (2021). The hashtag \#capitolsiegereligion was created to track many these themes. At one point, as the crowd chants 'Fight for Trump!', the camera panned over a cross and signs that read 'Jesus I trust in you', 'Jesus is King', 'Appeal to Heaven' and 'Jesus is my Savior, Trump is my President' (Parler, 3:35). The 'Appeal to Heaven' flag comes from America's Revolutionary era, but the prophet Dutch Sheets popularised it in his 2015 book of the same name. Large images of Mary and Jesus were also present (2:06), and several signs read 'God Bless America' (2:17) and 'Jesus Saves' (2:54). Some signs included specific verses: 'His Banner is Love' (3:48), 'Choose this day who you will serve' (2:33) or 'Righteousness exalts a nation but sins is a disgrace to any people' (1:41). One of the clearest examples of the merging of Christ and nation is a large sign that reads 'For God so loved the world that he gave his Son'. It depicts Christ on the cross. His contorted body bleeds into the American flag (2:28).

Patriotic songs filled the insurrectionary air. Worship songs were also common. Nearby, a choir sang: 'The Lord will fight the battle for his people when we cry aloud unto him. And he will crush the enemy...' (Parler, 2:22). Inside the Rotunda, a man sang 'Glory glory Hallelujah' before leading a prayer (2:43). Groups sang 'Amazing Grace' at several points (2:58, 4:02). Another choir sang 'Our God is an awesome God' (3:25). In a video posted at 2:08, a woman declared into a microphone that 'your angels surround this place'. Then, as the protestors pushed towards the Capitol, one man declared 'God is with us!' (Parler, 2:09). Later, a woman with a microphone loudly proclaimed her God-given dream about Trump and revival, comparing him to Hebrew Bible leaders who brought physical salvation (2:53). Periodic blasts of the ceremonial shofar pierced the yells $(2: 33 ; 2: 52 ; 3: 25)$ as prophecy was being fulfilled. One individual climbed the scaffolding with a book by the prophetess Elen G. White, founder of Seventh-Day Adventism (1:42). The book predicted that Protestant apostates would ally with Roman Catholicism (e.g. Joe Biden) to hasten America's demise.

Prayers were common, and people often thanked God for acting (Parler, 1:59; 1:48; 2:26; 2:54; 3:35; $4: 26)$. As the police used force against rioters, prayers for protection started $(5: 05 ; 5: 10)$. Warriors for God prayed after hearing of the death of a newly minted martyr (4:26). The most interesting prayer came from inside the Capitol. QAnon Shaman, flippantly swearing, entered the House chamber. After posing for photos, he joined others in prayer. One insurrectionist yelled 'Jesus Christ, we invoke your name! Amen! [Amen!]'. 'Let's all say a prayer in this sacred space' says QAnon Shaman as he picked up a bullhorn. Some knelt as others raised hands. Taking off his horns, his prayer blended conspiracy theories with praise to the 'divine omniscient, omnipotent and omnipresent creator God' for 'allowing us to get rid of the communists, the globalists and the traitors within our government' (New Yorker, 2021). QAnon Shaman walked out of the Capitol unmolested. Someone asked what he would say to those who doubted the police let him walk free: 'well a lot of people doubted a lot of prophets, saints and sages, a lot of people doubted Christ' (Parler, 5:06). One of Trump's favourite slogans is 'Promises made, Promises kept'. However, God did not seem to be sticking by his prophetrevealed promises. Perhaps some insurrectionists thought they were helping God's hand.

\section{Have Your Confession and Eat Cake Too (7-20 Jan 2021)}

Many Christian leaders on the Right and Left condemned the conspiracies and decried the assault. It was easy for many of them to do so since those prophesying Trump's victory tended to come from marginal charismatic groups, not mainline or evangelical congregations. The role of these Christians in actual violence is unclear. The assault might still have taken place without them. At the very least, 
as Brad Christerson argued in The Conversation on 12 January, they 'provided religious motivation' for the events. Miracles, visions and prophecies hardened opposition to Biden's victory - they erected alternative silos of knowledge wherein defeat could only stem from nefarious causes. On 6 January 2021, lethal violence followed in the wake of miraculous discourse employed in the service of seizing political authority for Trump. How would the prophets respond to a second wave of disappointment, especially after the election protests turned violent? As David Brooks wrote in The New York Times on 14 January, these prophecies have ignited a civil war within some congregations.

Stephen Strang's podcast, The Strang Report, provides a window into the hope, anger, frustration, confusion and pain in the following weeks. On the 8 January podcast, Caleb Cooper provided an eyewitness account of the 'blood-bought believers' at the Capitol, blaming the violence on Antifa. He described Christian songs, prayers, sermons and images, even as a flood of people rushed through the barricade and onto the Capitol steps. 'This was the voice of the American people being heard. And so prophetically.... a barrier just went down, I heard the word "breakthrough". Strang's 11 January podcast was sober. He addressed the prophecies about Trump's re-election. He still believed the election was stolen. However, God now required prayer for the Biden administration. He candidly remarked that in a way, all these prophecies and things, you know a lot of them were wishful thinking', later saying 'I don't understand what's happened, I just don't'. He did not regret promoting other people's prophesies (because he was sincere in promoted them). However, he admitted to 'missing this' and asked for grace. Although Strang frequently denounced violence by the Left, he said 'breaking into the capitol is far worse than burning a police precinct or burning down a store'.

The insurrection prompted many critiques of political prophecy, some of them coming from within the movement. Jeremiah Johnson was propelled into the spotlight by his prophecies about Trump's 2016 victory. His 2020 prophecies, however, did not come to pass. He issued a formal apology on 7 January, the day after the insurrection, for 'inaccurately prophesying that Donald Trump would win a second term'. He would not claim Trump lost because of lack of prayer, 'Nor will I proclaim, "Donald Trump actually won, so I was right, but now it has been stolen from him". He still maintained the legitimacy of his 2015 prophecies about Trump. However, 'God Himself anointed Donald Trump in 2016 and then removed him from office in 2020 because of his own pride and arrogance' (Jeremiah Johnson Ministries, 2021). Johnson then produced a three-part 'I Was Wrong' series on his YouTube channel, The Altar Global (released 8, 15 and 22 February). A New York Times article detailed the merciless response to his mea culpa. Johnson claimed on Facebook that he received 'multiple death threats and thousands upon thousands of emails from Christians saying the nastiest and most vulgar things'. He gave a damning assessment of the movement he helped create: 'I have been flabbergasted at the barrage of continued conspiracy theories being sent every minute our way and the pure hatred being unleashed. To my great heartache, I'm convinced parts of the prophetic/charismatic movement are far SICKER than I could have ever dreamed of (Brooks, 2021).

Another critic is Dr Michael L. Brown, a radio host and author. Four recent books chart his unease with the direction of the nation (Saving a Sick America, 2016), the Left's demonic assault (Jezabel's War With America, 2017) and his growing, but highly qualified, support for Trump (Donald Trump is Not My Savior, 2018, and Evangelicals at the Crossroads, 2020). In the wake of Biden's victory, Brown accepted defeat, called out Charismatic gullibility and demanded prophetic accountability (2021b). On 6 January, he criticised prophets who led people to believe in Trump's miraculous re-election: 'No amount of factual, contrary evidence will dissuade them' (2021a). In particular, he argued that some prophets did not properly condition predictions on faithful obedience. Further some of the prophets came close to idolising Trump. These twin errors might account for Biden's victory. False prophets 
should prove their integrity by admitting error (2021d). Many of Brown's followers turned on him. No prophet is accepted on his own Twitter feed after he criticises Trump.

Similarly, Joseph Matera called these prophets to confess because 'a wrong was committed against the tens of thousands of Christians'. Many agree 'on the need to reign in some of the excesses and abuses found in the contemporary apostolic movement' (2021c). Writing shortly after the inauguration, he said 'the day of reckoning has come for many in the prophetic movement'. Although some like Shawn Bolz, Jeremiah Johnson, and Kris Vallotton repented, others like Kat Kerr, Johnny Enlow, Hank Kunneman, Kenneth Copland, said 'Trump would remain president through divine intervention' (2021a). In an attempt to save the credibility of the prophetic, Matera outlined six specific things for which the prophets and prophecy voters needed to repent. These ranged from 'equating their prophecies with the canon of scripture' to 'engaging in QAnon predictions' (2021b). Johnson, Brown and Matera show one reaction to the frustration of Trump prophecies.

Rather than go down the road of self-critique and confession, other prophets hardened their resolve. Prophecies could always be recalibrated. For example, Pat Robertson on The 700 Club blamed Trump for inciting the mob. The president 'preempted' God's plan, and thus he would not stay in office (7 January 2021). Others continued to prophecy that Trump would either remain president or said his sphere of authority expanded globally (Boorstein, 2021; Duin, 2021). They threw good prophecies after bad. The sunk cost fallacy didn't apply in the spiritual realm, and loss was gain in this divine economy. Yet, hope deferred made the prophecies stick.

Many prophets doubled down in the days after the insurrection. Several appeared on Flashpoint on the The Victory Channel. The following detailed assessment of this one program is representative of a larger trend. The 7 January broadcast featured Gene Bailey (host), Hank Kunneman, Lance Wallnau, Mario Murillo, Dutch Sheets and Kat Kerr. Lance Wallnau claimed he was at the Capitol and said the violent provocateurs were 'organized Antifa radicals who led the break-in'. Crucially, he argued, the whole insurrection was set up by the Democratic-backed media. Alternative facts, therefore, were needed. The host, Gene Bailey, then assured the audience that 'There's great hope. Listen, Jesus didn't fall off his throne, and God didn't say "no we're done, aah forget it. I guess Biden won"”. Dutch Sheets then emphasised the demonic forces behind the stolen election: 'the reason Satan is so bent on doing this is because of the destiny hanging over this nation'. Even in the wake of this physical violence at the Capitol, his language was suffused with spiritual warfare. Later in the broadcast, he spoke of over 40 recent dreams and visions that were sent to him by others and declared God was saying 'this is not over'.

Gene Bailey replayed a clip of a new prophecy that was recorded shortly after the insurrection. In the recording, Hank Kunneman, repeated God's declaration that the year was 'twenty twenty won'. Defeat was nowhere in God's plan. He appealed to the miracles of Moses and Joshua, who triumphed over insurmountable foes. God, speaking through Kunneman, revealed "I have declared in the lips of the intercessors that this is a time over this nation of overthrowing, destroying, rooting out, tearing down structures"'. God's prophet called out those who compromised and gave up on Trump's election:

"for I [God] am going to cause a generation of those in political offices who have been a stench in this nation and they [that] have compromised, they [emphasis] shall be removed and new faces shall take their place as a new party shall arise. Why?" says the Lord, "because a righteous rebellion is upon the land". 
God said to "watch how my spirit moves in a way that is so unusual in the days to come" and highlighted big changes that would come "in the next few weeks"'. Kunneman argued that "God knew when that vision came that there would be an attempted coup or a government takeover [perpetrated by the Left]'. The prophets were correct: 'President Trump won, he won by a landslide. It's not that he didn't get re-elected, you know. There's prophecies that he would get elected. He did get re-elected. He won, and he's still going to win'.

The host, Gene Bailey, picked up on Kunneman's new prophecy of a 'righteous rebellion' before turning to another leader, Kat Kerr. She is known for her startling prophecy from the stage at a 2017 inaugural prayer breakfast (the prophet Jonathan Cahn was the main speaker). At this event, Kerr prayed 'I thank you God that Trump will be here for eight years in the White House, and then Pence for eight years in the White House. And who Pence picks as vice president will be president for eight years in the White House' (Prayer Breakfast, 2017). She declared twenty-four years of God-promised leadership. Four years later, the day after the insurrection, she argued on Flashpoint that God's plan was still on course. God 'told me to start getting cake and telling everyone to celebrate' as she lifts cake to the camera. She prophesied earth-shaking events that would usher in the second coming of Trump:

"'So stand in the light or run to the darkness, but nothing will stop me [God] from my plan of putting my son Donald Trump back in that White House. Even if they inaugurate the villain and try to put him there, I will kick him out. I will remove him, and I'll remove every obstacle that's in the way. Maybe they'll show that in the news", says your God'.

She made it absolutely clear that her 2017 prophecy was about two consecutive terms in office, followed by eight Pence years and then eight years of Pence's pick as vice president. She zeroed in on the spiritual war, claiming ' $\mathrm{I}$ [Kerr] command part of the army of heaven and I send them all over this world'. She then detailed the movements of angelic forces who were moving closer and closer to the Capitol.

\section{Living Without God's Anointed (20 Jan and Beyond)}

Some prophets continued to foretell an imminent divine intervention. Somehow, it would be Trump at that podium on 20 January holding his hand on a Bible. How did they react to another dose of hope deferred? Stephen Strang's podcast, again, is instructive. On 19 January, the day before the inauguration, the podcast featured Bobby Conner. Strang said 'there are reasons to believe he really did win, and if that's the case, the prophecies came true'. God's purposes were obscure, and he might be preparing the way for an imminent revival. Strang and Conner worried that frustrated prophecy would be coupled with the insurrection and used to discredit Christianity in the public sphere. By the 28 January broadcast, the fear crystalised in Strang's mind: the cancellation of Christianity. On 21 February, Frank Amedia stood behind his 2017 word from God that Trump would serve a second term, even as he wrestled with the question, 'Lord, did I miss it?' He spoke of the events as a 'grieving process' for Christians. Part of how he reconciled prophetic hope with the reality of Biden's election was by highlighting the conditional nature of God's promises. The next day Amedia posted a video on the POTUS Shield website. He argued that Trump's re-election was conditioned on 'humility before God'—a condition which Trump did not meet.

On the last day of February, Mike Bickle, founder of the International House of Prayer-Kansas City, came on Strang's podcast. He argued that the forces of escalating light were running in tandem with darkness, and in the coming battle, Jesus would overrule demonic plans. The spiritual battle was not 
over, and indeed it would become more intense as the Democrats enacted their agenda. In Strang's later podcasts, the persecution of Christians is a major theme. He seems aware that the Left might justify its attacks on Christianity by associating it with violent insurrection. However, the persecution itself is not justified, and suffering for Christ shows Christians that they are on the right path. As the Left 'cancels' Christianity, cancelling proves Christianity to be true. Similar themes appear in his recent book, God and Cancel Culture: Stand Strong Before It's Too Late. It promises to equip Christians to live under socialism and a one-world government that could signal the appearance of the Antichrist.

Michael L. Brown continues to be a strong voice for self-criticism from within the prophetic movement. The day after the inauguration, he wrote on Ask Dr. Brown that 'Joe Biden, not Donald Trump, is the President'. Prophets should 'admit your error, take full responsibility, and do not, under any circumstances, continue to put a false hope into the hearts of God's people'. Brown said prophets were now threatening followers who expressed doubt. 'This is deep deception', he said, 'and serious spiritual manipulation'. Unrepentant prophets 'are moving into complete spiritual fantasy and leading others with' them (2021c). Brown was one of eighty-five leaders to sign the 'Prophetic Standards Statement' released on 29 April. It was also signed by Jeremiah Johnson, Joseph Mattera and Steven Strang, along with well-known academics like Wayne Grudem and Craig Keener. The Statement cautioned those who follow prophets out of a desire for the fantastic and a curiosity about the future. Most of the warnings were directed at errant prophets themselves. They acknowledged that social media provided a wide audience for anyone claiming inspiration, and therefore increased regulation was needed. If a prophet threatened sceptical followers with divine judgement, this was a spiritual manipulation. And those who continually fail to accurately prophecy might actually be damned. Inaccurate prophets should genuinely repent, and if their error was public, the repentance should be public. Above all, the 'Prophetic Standards Statement' tried to promote a process whereby genuine prophetic words might be separated from spurious ones. This is a difficult task for a movement that compares the dynamic unpredictability of the Holy Spirit to an overflowing river and an allconsuming fire. Can the river be directed without being dammed or the fire controlled without being quenched? 'The 'Prophetic Standards Statement' aims to do just that.

Whereas many believers in prophecy now express caution, contrition and humility, others remain largely unmoved. For Dutch Sheets, prophetic frustration is the mother of invention. He exemplifies the sobered yet unrepentant prophet. Four days after the inauguration, he spoke on Conversations with Dutch on common misunderstandings of the prophetic. The failures of the faithful frustrated God's plans. God, he argued, spoke in code, and sometimes he did not get what he wants. The prophets always had disclaimers attached to their promises of re-election. Perhaps they really foretold 'a person like Trump' or 'another Trump coming' or a future 'second term'. He ended by confidently asserting that the prophets succeeded, and this was proven by new dreams. For those willing to wait, the phoenix would rise from the ashes.

Other prophets are not sobered in the least. Jeff Janson made headlines for declaring on the 16th of March that even after the 'fake inauguration', the 'military is in control' (Lemon, 2021). He made similar statements in late May (Cagnassola, 2021). The collection of leaders at Elijab Streams are emboldened by the gap between their prophecies and reality. Trump never conceded, and the military would expose the corruption and return Trump to power. As this article has shown, in the midst of doubt about the election, many of the prophets placed certainty in the military. This further cemented the already tight relationship between the religious Right and the armed forces.

Kat Kerr, who prophesied twenty-four years of godly leadership, dyed her hair pink and dug in her heels. On the Elijah Streams channel on 17 March 2021, she said 'Trump is actually at this moment 
our actual president. He won the election', and God would act 'really soon'. A viewer asked how she discerned God's voice. She replied:

'Almost everything I say is revelation. I'm here to share revelation that comes from the mind of the Father. It's what He says over what man says. ... Number one, I never will research anything. He [God] doesn't let me research. I don't listen to other people's things. Sorry out there, I don't listen to their blogs. I don't watch their other stuff that's going on. I don't read other people's books. He won't let me do that. He wants my soul to be free of any kind of clutter other than what He says. ... When He said He'd take the virus [COVID-19] off the earth, that was Him. When He said the mask would be a thing of the past, that was Him. When He said Trump would be put right back as sitting as their president, that was Him'.

On the 19 May broadcast, she stuck by her election prophecies and told the audience to prepare for a party. This prophet was an island; a floating island caught in the current of Elijah's stream. No amount of reasoning, no amount of research, no amount of disconfirming evidence could change her mind. Direct access to God's mind made all other knowledge suspect. Again, on 15 September, she prophecied a 'day of celebration coming up that will spread around this world' when Trump returns to the White House (possibly around Thanksgiving or Christmas).

It would be a mistake to assume that these prophets are marching confidently into obscurity. For example, Lance Wallnau continues to prophesy the Big Lie and the return of Trump. On the 26 August Firewall broadcast, he offered a 'prophetic word' for the present moment (after the lethal explosion at the Kabul airport). He recited a 1967 prophecy by Kenneth E. Hagin and uttered his own new word from the Lord. There would be an imminent mass conversion of people who would become 'activists of the Christian populist movement'. Between prophecies, he plugged Mike Lindell's slippers that 'feel like rabbit fur on the inside, suede-like leather on the outside'. In a recent Atlantic article, Anne Applebaum said Lindell, the Charismatic pillow salesman who has been the leading proponent of the election fraud theory, 'may well be doing more damage to American democracy than anyone since Jefferson Davis' (2021). Wallnau, wearing Lindell's slippers, told the audience, 'you might as well walk comfortably while you're warring in these days'. These old guard prophets are cosily marching to war, not retirement.

The events of the last year have also raised up new leaders in the prophetic movement. For example, before COVID-19, Clay Clark was known as a successful entrepreneur with a nationwide following. He used his platform to challenge COVID-19 regulations and vaccines, later advocating the stolen election theory. 'If you want to screw up your life, mess with the prophets', Clark warned on the 6 July Elijah Streams broadcast. He is leading rallies across the country that are drawing upwards of 10,000 people. Many of the prophets are speaking, along with General Michael Flynn and Jim Caviezel (who played Jesus in Mel Gibson's The Passion of the Christ). Speakers promote QAnon conspiracies, particularly those related to the stolen election and COVID-19, and they vigorously oppose changing sexual mores, secularisation and Critical Race Theory. They refuse to be lectured on the science of vaccines by anyone who believes that a foetus is not a human with rights or by those who argue that there is no difference between a transgender woman and a natal woman. Further, they argue that scientists were not following the science when they deemed protests against pandemic restrictions to be a health hazard, even as many called protests over racism a health necessity - as if a virus behaved one way during Right-wing protests and another way during Leftwing protests. Thus prophecy and the stolen election theory became further enmeshed in America's hot-button issues. In this context, Clark believes he is God's uniquely chosen culture warrior (Strang 
Report, 1 June 2021). In 2013, Kim Clement prophesied that God would use a man named 'Clark' and another named 'Donald' to restore America (Beverley, 25). The August 2021 'ReAwaken America Tour' (Michigan) opened with a video of Kim Clement's prophecy. On the 6 July Elijah Streams broadcast, Clark again claimed that God directly 'called me by name, by name'. He foretold a great revival. As part of this return to God, Christ's kingship should be visibly displayed in every public place. If people object, 'well then leave the country, cuz this is a Christian nation'. Only those willing to acknowledge or tolerate Christ's kingship belong in the nation. Clark articulates unvarnished prophetic populism, and many Americans still find it appealing.

\section{Conclusion}

This article described the origin and impact of 'prophetic populism'. These 'Trump supporters aligned themselves with populists and exhibited traits common to populists like the denigration of 'elite' forms of knowledge. This anti-elitism is evident in the publishers they choose, the news sources they promote and the denominations they associate with. However, even as they retreat into their own silos of knowledge, they are willing to connect their movement with other conspiratorial and militaristic groups. They differentiate between 'real' and less-than-real Americans, and the difference hinges on the response to God's prophetic word-not race, gender or nation of origin. Through the direct revelation of God, prophetic populists differentiate the 'real results' of the election (as revealed by God) from the real results of the election (as certified through democratic and constitutional means). Democratic results are relativised by divine revelation.

Three consecutive disappointments took their toll on prophetic populism: the declaration of Joe Biden as president-elect in November 2020, the certification of his victory in early January 2021 and the inauguration later that month. Being associated with violent insurrection was another blow. There were three main responses to these disappointments. First, some felt chastened by the gap between their prophecies and the reality of Biden's victory. Others sought to exert greater quality control over the prophetic process. A third group has become more combative as the gap widens between prophecy and reality. All three groups, however, still believe God speaks through prophets.

If the period from 3 November 2020 to 20 January 2021 were a fire, what aspects of prophetic populism emerged from the flames? This article has demonstrated the flexibility of beliefs in divine involvement and the resilience of these beliefs in light of weighty disconfirming evidence. Four core beliefs seem to have survived. First, for most of the prophets, it appears the belief that the election was stolen remains intact. As a result, every time the Left turns the thumbscrew by enacting their agenda, the prophets interpret this as another painful reminder of an illegal power grab. Second, the belief in a cosmic war between good and evil seems to have heightened. Third, they speak of a time of increasing persecution in the form of 'cancel culture'. Some of the prophets recognise that this persecution is owing to their actions under the Trump administration (and especially because of their involvement in the resistance to Biden's election). However, because they believe the election was stolen, they feel as if they are being 'cancelled' for protesting the theft of their own democracy. They do not view themselves as anti-democratic but as the last best hope for democracy. Finally, some prophets seem chastened and sober. However, as Ruth Graham wrote in The New York Times on 11 February, 'the popularity of self-appointed prophets shows no signs of waning'. Consider Jeremiah Johnson who, more than most others, confessed his prophetic error. His many 'I Was Wrong' writings and videos were another way of saying 'I am right'. They elevated his status among repentant prophecy voters. Confession reinforced the claim that he was uniquely chosen of God. After the 
insurrection, he claimed God uniquely revealed to him how 'sick' the prophetic movement was. The one chosen by God to identify the sickness was well placed to administer the cure.

These prophets are a relatively new force in politics. They entered the arena by hitching Elijah's fiery chariot to the thrice-married, twice-impeached, one-term president. For some, this is a badge of honour; for others, a mark of disgrace. Emerging through the flames, it seems likely their utterances will be a potent force in future campaigns. My prediction? Their words will continue to shape the future they prophesy.

\section{Bibliography}

Amedia, F. (2021). "For Sake Of His Word and His Glory". YouTube (Feb 22, 2021). Online: https://www.youtube.com/watch?v=K6CMDTUT-oI\&t=104s (Retrieved 1 March 2021).

Applebaum, A. (2021). 'The My Pillow Guy Really Could Destroy Democracy'. The Atlantic (29 July 2021). Online: https://www.theatlantic.com/ideas/archive/2021/07/mike-lindells-plot-destroy-america/619593/. (Retrieved 1 Aug 2021).

Berry, D. (2020). "Voting in the Kingdom: Prophecy Voters, the New Apostolic Reformation, and Christian Support for Trump”. Nova Religio 23, (4):69-93.

Beverley, J.A. (2020a). God's Man in the White House: Donald Trump in Modern Christian Prophecy. Riviera Beach, FL: Castle Quay.

Beverley, J.A. (2020b). The QAnon Deception: Everything You Need to Know About the World's Most Dangerous Conspiracy Theory. Concord, NC: EqualTime.

Boorstein, M. (2021). "For some Christians, the Capitol riot doesn't change the prophecy: Trump will be president". The Washington Post (14 Jan 2021). Online: https://www.washingtonpost.com/religion/2021/01/14/prophetsapostles-christian-prophesy-trump-won-biden-capitol/ (Retrieved 16 Jan 2021).

Brooks, D. (2021). "Trump Ignites a War Within the Church". New York Times (14 Jan 2021). Online: https://www.nytimes.com/2021/01/14/opinion/trump-evangelicals.html (Retrieved 14 Jan 2021).

Brown, M.L. (2017). Saving a Sick America: A Prescription for Moral and Cultural Transformation. Nashville: Thomas Nelson.

Brown, M.L. (2018). Donald Trump is not My Savior: An Evangelical Leader Speaks His Mind About the Man He Supports as President. Shippensburg, PA: Destiny Image.

Brown, M.L. (2019). Jezabel's War With America: The Plot to Destroy Our Country and What We Can Do to Turn the Tide. Repr; Lake Mary, FL: FrontLine, 2019.

Brown, M.L. (2020). Evangelicals at the Crossroads: Will We Pass the Trump Test? Concord, NC: Equal Time.

Brown, M.L. (2021a). "The Power of Faith vs. the Danger of Delusion". The Stream (6 Jan 2021). Online: https:/ / stream.org/the-power-of-faith-vs-the-danger-of-delusion/ (Retrieved 10 Feb 2021).

Brown, M.L. (2021b). "Joe Biden, President of the United States by the Sovereign Will of God". The Stream (20 Jan 2021): Online: https://stream.org/joe-biden-president-of-the-united-states-by-the-sovereign-will-of-god/ (Retrieved 10 Feb 2021).

Brown, M.L. (2021c). "A Strong Appeal to Those Who Prophesied Trump's Reelection” (21 Jan 2021). Online: https://askdrbrown.org/library/strong-appeal-those-who-prophesied-trump-s-reelection (Retrieved 10 Feb 2021).

Brown, M.L. (2021d). "A Rape Victim Speaks Up for the Unborn”. YouTube (Jan 26, 2021). Online: https://www.youtube.com/watch?v=J1NqF1xjos8\&t=999s (Retrieved 10 Feb 2021).

Cagnassola, M. E. (2021). "Pastor Jeff Jansen Says, 'Have Faith,' Trump Is 'Coming Back Into Power Very, Very Quickly"'. Newsweek (24 May 2021). Online: https://www.newsweek.com/pastor-jeff-jansen-says-have-faithtrump-coming-back-power-very-very-quickly-1594311 (Retrieved 27 May 2021).

Cahn, J. (2017). The Paradigm: The Ancient Blueprint that Holds the Mystery of Our Times. Lake Mary, FL: FrontLine.

Christerson, B. and Flory, R. (2017). The Rise of Network Christianity; How Independent Leaders Are Transforming the Religious Landscape. Oxford: Oxford University Press.

Christerson, B. (2021). "How self-proclaimed 'prophets' from a growing Christian movement provided religious motivation for the Jan. 6 events at the US Capitol". The Conversation (12 January 2021). Online: 
162 Prophetic Populism and the Violent Rejection of Joe Biden's Election: Mapping the Theology of the Capitol Insurrection

https:/ / theconversation.com/how-self-proclaimed-prophets-from-a-growing-christian-movement-providedreligious-motivation-for-the-jan-6-events-at-the-us-capitol-152879 (Retrieved 11 Feb 2021).

Clark, C. "The Truth Will Set Us Free / God Has the Trump Card". Elijah Streams (6 July 2021). Online: https://www.elijahstreams.com/watch/watch.php?ID=929 (Retrieved 20 July 2021).

C-SPAN, "President Trump Remarks at Evangelical Rally". C-SPAN (3 Jan 2020). Online: https://www.cspan.org/video/?467813-1/president-trump-speaks-evangelical-rally-miami (Retrieved 1 July 2020).

Dias, E. and Graham, R. (2021). "How White Evangelical Christians Fused With Trump Extremism". The New York Times (11 Jan 2021). Online: https://www.nytimes.com/2021/01/11/us/how-white-evangelical-christiansfused-with-trump-extremism.html (Retrieved 12 Jan 2021).

Dreher, D. (2020), "What I Saw At The Jericho March". The American Conservative (12 Dec 2020). Online: https://www.theamericanconservative.com/dreher/what-i-saw-at-the-jericho-march/ (Retrieved 14 April 2021).

Duin, J. (2021). "The Christian Prophets Who Say Trump Is Coming Again". Politico (18 Feb 2021). Online https://www.politico.com/news/magazine/2021/02/18/how-christian-prophets-give-credence-to-trumpselection-fantasies-469598 (Retrieved 19 Feb 2021).

The Eric Metaxas Show, "Lance Wallnau Shares What He Considers A 'Prophetic' Look Into Our Current Political Situation". YouTube (20 Nov 2020). Online: https://www.youtube.com/watch?v=inQuzVqPrPY (Retrieved 15 Jan 2021).

Flashpoint, "Flashpoint with Mario Murillo, prophetic voices speaking". YouTube (7 Jan 2021 Broadcast). Online: https://www.youtube.com/watch?v=C3ywH1HHv0M (Retrieved 10 March 2021).

Graham, R. (2021). "Christian Prophets Are on the Rise. What Happens When They're Wrong?” The New York Times (11 Feb 2021). Online: https://www.nytimes.com/2021/02/11/us/christian-prophets-predictions.html (Retrieved 11 Feb 2021).

Grantham-Philips, W. (2020). "Pastor Paula White calls on angels from Africa and South America to bring Trump victory”. US A Today (5 Nov 2020). Online: https://www.usatoday.com/story/news/nation/2020/11/05/paulawhite-trumps-spiritual-adviser-african-south-american-angels/6173576002/ (Retrieved 28 Jan 2021).

Groeger, L.V., Kao, K., Shaw, A., Syed M. and Eliahou, M. (2021) "What Parler Saw During the Attack on the Capitol”. ProPublica (17 January 2021). Online: https://projects.propublica.org/parler-capitol-videos/ (Retrieved 20-25 January 2021).

Hagee, J. (2018) Earth's Last Empire: The Final Game of Thrones. Franklin, TN: Worthy.

The Hill, "LIVE COVERAGE: Capitol overrun by pro-Trump mobs". The Hill (06 Jan 2021). Online: https://thehill.com/homenews/campaign/532854-live-coverage-pro-trump-protesters-gather-in-washington (Retrieved 13 Jan 2021).

Ho, G. (2018). TRUMPography: How Biblical Principles Paved the Way to the American President. Bloomington, IN: iUniverse.

Jericho March. (2021). "Statement from Jericho March”. https://jerichomarch.org (Retrieved 12 Jan 2021).

Johnson, J. (2021). "My Public Apology and Process" (January 7, 2021). Online: https://cf.jeremiahjohnson.tv/jimapology-01-07-eub?fbclid=IwAR2cV2hOJ1AtbTUOH2UzNlsss006VfiVcf_bbaoUNRzjWfhHgop5VP60X-k (Retrieved 22 Feb 2021).

Johnson, J. (2021). "I Was Wrong." YouTube (8-22 Feb 2021). Online: https://www.youtube.com/channel/ UCFEewYSkc3nbkOiFHTtDLDw (Retrieved 22 Feb 2021).

Jones, R.P. (2021). "Taking the white Christian nationalist symbols at the Capitol riot seriously". Religion News Service (7 January 2021). Online: https://religionnews.com/2021/01/07/taking-the-white-christian-nationalistsymbols-at-the-capitol-riot-seriously/ (Retrieved 11 Jan 2021).

Kerr, K. "Presidential Inaugural Prayer Breakfast". YouTube (Jan 25, 2017). Online: https://www.youtube.com/ watch?v= UC_eySMKVEM (Retrieved 10 Feb 2021).

Kerr K. and Shultz, S. (2021). "Wednesdays with Kat and Steve!" YouTube (17 March 2021). Online: https://www.youtube.com/watch?v=2qkNCT0IqHM (Retrieved 10 April 2021).

Kerr K. and Shultz, S. (2021). "Wednesdays with Kat and Steve!" YouTube (19 May 2021). Online: https://www.youtube.com/watch?v=kgrxRMJ94mA (Retrieved 27 May 2021).

King, A.C. (2016). America Return to God: Repent from Sin, Rebuild the Wall, Repair the Gates, Restore the Dream. Albany, NY: Elijah List. 
Lemon, J. (2021). "Evangelical 'Prophet' Claims Military Carrying Out Coup to Reinstate Trump as President". Newsweek (18 March 2021). Online: https://www.newsweek.com/evangelical-prophet-claims-military-carryingout-coup-reinstate-trump-president-1577162 (Retrieved 18 March 2021).

Markoe, L. (2018) "Did Trump fulfill a divine prophecy? What to expect from a new Liberty University film". Washington Post (31 May 2018). Online: https://www.washingtonpost.com/news/acts-of-faith/wp/2018/05/31/ did-trump-fulfill-a-divine-prophecy-what-to-expect-from-a-new-liberty-university-film/ (Retrieved 2 Feb 2021).

Mattera, J. (2021a). “The Day of Reckoning for the Prophetic Movement has Come: Part 1" (21 Jan 2021). Online: https://josephmattera.org/reckoning-movement-come/ (Retrieved 10 Feb 2021).

Mattera, J. (2021b). "The Day of Reckoning for the Prophetic Movement has Come: Part 2" (26 Jan 2021). Online: https://josephmattera.org/reckoning-movement-come-part-2/ (Retrieved 10 Feb 2021).

Mattera, J. (2021c). "Is It Wrong To Publicly Judge the Prophets for Erroneously Predicting a Trump Re-Election?” (27 Jan 2021). Online: https://josephmattera.org/wrong-judge-prophets-2/ (Retrieved 10 Feb 2021).

McGuire, P. and Anderson, T. (2018). Trumpocalypse: The End-Times President, a Battle Against the Globalist Elite, and the Countdown to Armageddon. New York: FaithWords.

New Yorker, “A Reporter's Footage from Inside the Capitol Siege". The New Yorker (17 Jan 2021). Online: https:/ /www.youtube.com/watch?v=270F8s5TEKY\&feature=emb_title (Retrieved 18 January 2021).

Posner, S. (2020). Unholy: Why Evangelicals Worship at the Altar of Donald Trump. New York: Random House.

'Prophetic Standards Statement' (29 January 2021). Online: https://propheticstandards.com (Retrieved 27 May 2021).

Reuters, ' $53 \%$ of Republicans view Trump as true U.S. president -Reuters/Ipsos', Reuters (24 May 2021). Online: https://www.reuters.com/world/us/53-republicans-view-trump-true-us-president-reutersipsos-2021-05-24/ (Retrieved 27 May 2021).

Rogers, R.L. (2021). 'Spiritual Warfare and the Apocalypse: The Religious Framing of Political Violence in American Cultural Nationalism', in Crews, G.A., Markey, M.A. and Kerr, S.E.M. (eds), Mitigating Mass Violence and Managing Threats in Contemporary Society. Hershey, PA: IGI Global, 2021), 85-104.

Rowley, M. (2021). Trump and the Protestant Reaction to Make America Great Again. London: Routledge.

Rowley, M. and Hodgson, N. (2022). Miracles, Political Authority and Violence in Medieval and Early Modern History. London. Routledge.

Sheets, D. (2015). An Appeal to Heaven. Dallas: Dutch Sheets Ministries.

Sheets, D. (2021). "Where do we go from here?" YouTube (24 Jan 2021). Online: https://www.youtube.com/ watch?v = UYNU8cC-Mbc (Retrieved 1 March 2021).

Smietana, B. (2021). "Jericho March Returns to DC to Pray for a Trump Miracle”. Christianity Today (5 January 2021). Online: https://www.christianitytoday.com/news/2021/january/jericho-march-dc-election-overturn-trumpbiden - congress.html (Retrieved 10 Jan 2021).

Smietana, B. (2021). "Pro-Trump prayer meeting filled with calls for a 'miracle"'. Religion News Service (6 January 2021). Online: https://religionnews.com/2021/01/06/pro-trump-prayer-call-metaxas-michele-bachmann-coup-mobcapitol/ (Retrieved 12 Jan 2021).

Strang, S.E. (2018a). God and Donald Trump. Lake Mary, FL: FrontLine.

Strang, S.E. (2018b). Trump Aftershock: The President's Seismic Impact on Culture and Faith in America. Lake Mary, FL: Charisma House.

Strang, S.E. (2020a). God, Trump and the 2020 Election: Why He Must Win and What's at Stake if He Loses. Lake Mary, FL: FrontLine, 2020.

Strang, S.E. (2020b). God, Trump, and COVID-19: How the Pandemic Is Affecting Christians, the World, and America's 2020 Election. Lake Mary, FL: FrontLine.

Strang, S.E. (forthcoming). God and Cancel Culture: Standing Strong Before It's Too Late. Lake Mary, FL: FrontLine.

The Strang Report (2020-2021). Online: https://podcasts.apple.com/us/podcast/strang-report/id997965301).

Taylor, M. (2019). The Trump Prophecies: The Astonishing True Story of the Man Who Saw Tomorrow... and What He Says Is Coming Next. Rev. ed.; Crane, MO: Defender.

Van der Tol, M. and Rowley, M. (2021). 'A posture of protest? The search for Christian identity in a post-secular society: between secularised eschatology and a sacralisation of history'. International Journal of Religion.

Trump, D.J. (2021). "Speech 'Save America' Rally Transcript January 6”, Rev.com. Online: https://www.rev.com/ $\mathrm{blog} /$ transcripts/donald-trump-speech-save-america-rally-transcript-january-6 (Retrieved 10 Jan 2021).

Wallnau, L (2016). God's Chaos Candidate: Donald J. Trump and the American Unraveling. Keller, TX: Killer Sheep Media. 
164 Prophetic Populism and the Violent Rejection of Joe Biden's Election: Mapping the Theology of the Capitol Insurrection

Wallnau, L. (2020). God's Chaos Code: The Shocking Blueprint that Reveals 5 Keys to the Destiny of Nations. Keller, TX: Killer Sheep.

The 700 Club (2021). YouTube (January 4, 2021). Online: https://www.youtube.com/watch?t=92\&v=7TJppiwt EC0\& feature $=$ youtu.be (Retrieved 16 Jan 2021).

The 700 Club (2021). YouTube (January 7, 2021). Online: https://www.youtube.com/watch?v=GVMSsmWqi7 o\&list=PLg2gWMJDF4FZOkPcLsxeucNRRyVrjoSui\&index=8 (Retrieved 16 Jan 2021). 